\title{
Genesis and sedimentary record of blind channel and islands of the anabranching river: An evolution model
}

\author{
Isabel T. Leli ${ }^{\text {a,b,* }}$, José C. Stevaux ${ }^{\text {b,c,d }}$, Mário L. Assine ${ }^{\text {b }}$ \\ ${ }^{\text {a } U N I O E S T E / M a l . ~ C a ̂ n d i d o ~ R o n d o n, ~ P R, ~ B r a z i l ~}$ \\ ${ }^{\mathrm{b}}$ Institute of Geosciences and Exact Sciences, UNESP/São Paulo State University, Rio Claro, Brazil \\ c Center of Geoscience Applied to Petroleum, UNESPetro/Rio Claro, SP, Brazil \\ d Post-graduation Program on Freshwater Ecology, UEM/Maringá, PR, Brazil
}

\section{A R T I C L E I N F O}

\section{Article history:}

Received 2 May 2017

Accepted 2 May 2017

Available online 5 May 2017

\section{Keywords:}

Anabranching rivers

Blind channel

Lateral bar

Paraná River

River ecology

Fluvial sedimentology

\begin{abstract}
A B S T R A C T
Blind channel (BC) is a fluvial feature formed by attachment of a lateral sand bar to an island or riverbank. It consists of a 10- to 20 -m wide and hundreds to thousands meters long channel, parallel to the island or bank, closed at its upstream end by accretion to the island. It is an important feature in anabranching rivers that plays an important role in both the island formation and river ecology. This paper discusses the formation processes, functioning, evolution, and the sedimentary record of a blind channel, related landforms, and its context on island development in the Upper Paraná River. The evolution of this morphologic feature involves (1) formation of a lateral or attachment bar beside an island with the development of a channel in between; (2) vertical accretion of mud deposits during the flood and vegetal development on the bar; (3) the upstream channel closure that generates the blind channel; and (4) annexation of the blind channel to the island. A blind channel is semilotic to lentic, that is not totally integrated to the dynamics of the main active channel and that acts as a nursery for fingerlings and macrophytes. The sedimentary facies succession of BCs are relatively simple and characterized by cross-stratified sand covered by organic muddy sediments. Based on facies analysis of 12 cores, we identified a succession of environments that contribute to the formation of islands: channel bar, blind channel, pond, and swamp. Blind channel formation and its related bar-island attachment are relevant processes associated with the growing of large island evolution in some anabranching rivers.
\end{abstract}

C 2017 Published by Elsevier B.V.

\section{Introduction}

Blind channel (BC) is a channel closed in its upstream mouth developed alongside islands or riverbanks through processes of lateral bar attachment (Stevaux, 1994; Leli et al., 2013). It is a very common morphology in the Upper Paraná River (Leli et al., 2013; Leli, 2015) where it is locally called ressaco - and is also registered in other tropical anabranching rivers such as the Madeira, Amazonas, and Negro (Latrubesse and Stevaux, 2015). Based on a four-decade analysis of aerial-photography and satellite images, Stevaux (1994) presented the first reference to the BC in the Upper Paraná, identified lateral bar attachment as a main process in $\mathrm{BC}$ generation and floodplain development, and estimated a lateral growth rate of $500 \mathrm{~mm} \mathrm{y}^{-1}$. Lateral bar attachment is the pioneer process in $\mathrm{BC}$ formation, and they are related to zones of low-flow velocity generated by flow separation at the head of preexisting islands (Santos, 2010). As an environment protected

\footnotetext{
* Corresponding author at: UNIOESTE/Mal. Cândido Rondon, PR, Brazil. E-mail address: isabel.leli@unioeste.br (I.T. Leli).
}

from the river flow, BCs offer sustainability for specific species and act as a link between the lentic and lotic conditions. Consequently, BC environment has remained the focus of study by biologists and ecologists in the Upper Paraná River (Agostinho et al., 2004a, 2004b). In this paper, we present a model for genesis and evolution (from the bar formation phases to its complete incorporation to the island), functioning (hydrodynamic and water quality characteristics), and stratigraphic architecture (facies analysis and model) of the BC in the Upper Paraná River (Fig. 1).

\section{Study area}

The Upper Paraná River and its main tributaries are practically a sequence of large artificial lakes constituted by 150 large reservoirs (>15 $\mathrm{m}$ in height). A 235-km reach from Porto Primavera to Itaipu Hydroelectric Power Station is the only sector without direct impoundment and the focus of this study (Fig. 1). The flow of the Upper Paraná is regulated and experienced strong changes in its flow regime (magnitude, recurrence, and permanence), tension (flattering in the annual hydrograph), suspended sediment concentration (reduction more than 100 times after dam construction), and armoring effect in the 


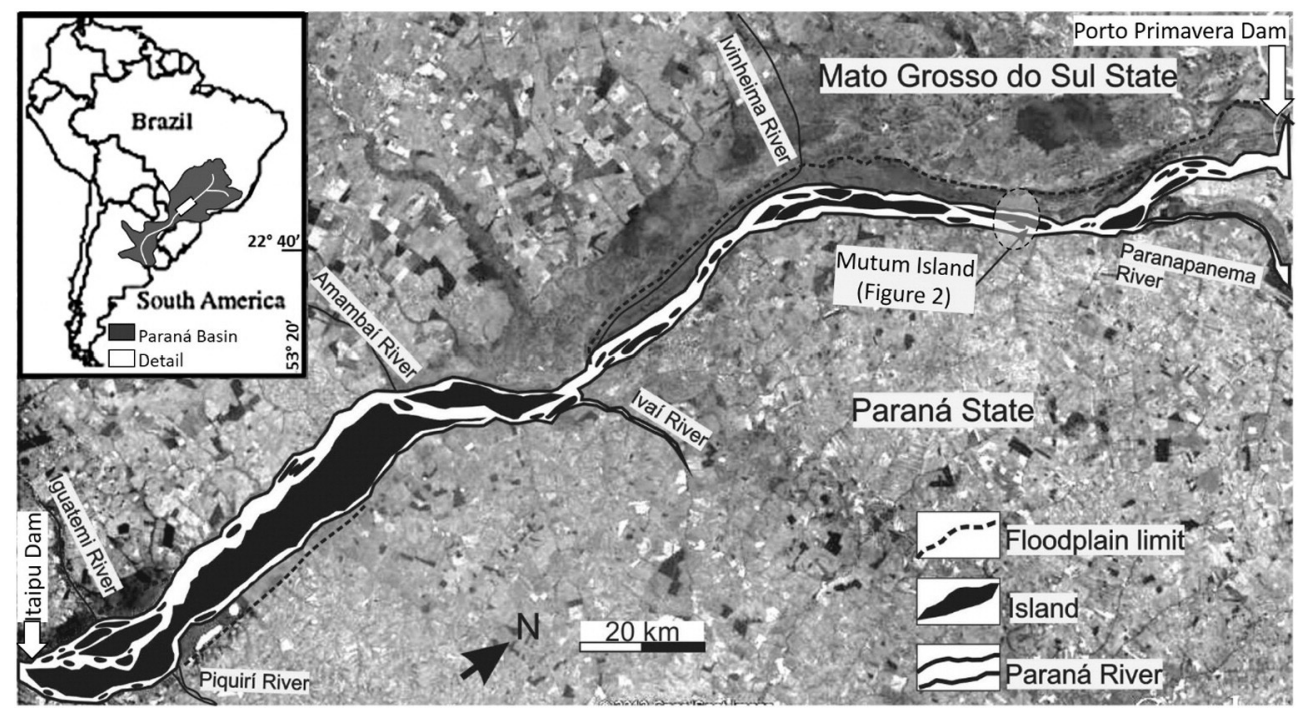

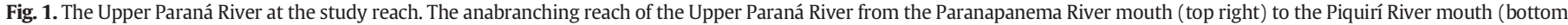
left) with 264 islands.

bed channel (Stevaux et al., 2009). As most of the large rivers of the world, the Upper Paraná River is anabranching and has been described as low to moderate anabranching with low sinuosity and a relatively abundant sandy load (Latrubesse, 2008). Elongated islands and sandy bars (Fig. 1) characterize the channel in the studied area. The islands are varied in terms of size (since few tens to thousands of meters in length), age (decades up to thousands of years), and genesis (intra- or extra- channel processes) (Stevaux et al., 2009; Leli, 2015). The river channel in the study reach is $4 \mathrm{~km}$ wide and is controlled in its left bank by the erosion-resistant sandstone of the Caiuá Formation. The BC research has concentrated on Mutum, Porto Rico, and Santa Rosa Islands, which are located near Porto Rico Town, $25 \mathrm{~km}$ downstream of the Paranapanema River mouth at the border of the states of Paraná and Mato Grosso do Sul, south of Brazil (Figs. 1, 2).

The BCs were surveyed with a topographic differential global positioning system (PROMARK 100-200). Water flows were measured with an ADCP RD, Rio Grande, $600 \mathrm{kHz}$; bathymetry was surveyed with a FURUNO GP 1650-F echo sound; and water parameters were measured with an Horiba multiparameters equipment. The decadal temporal and spatial evolution of the $\mathrm{BC}$ was reconstructed using vertical aerial photographs from 1963 and 2013 satellite images. Facies analyses were based on the study of 12 cores (Fig. 2), and absolute dating ( 9 ${ }^{14} \mathrm{C}$ and 1 luminescence dating) allowed the estimation of sedimentary rates and to sustain a temporal model for BC evolution. Vegetation data were obtained from Fachini (2001), Corradini et al. (2008), Stevaux et al. (2013), Ramirez (2014), and Zviejkovski (2013).

\section{Morphology, hydrology, and limnology}

The $\mathrm{BC}$ is a geomorphological element developed approximately parallel to islands and river banks, 10 - to 20 -m wide upstream closed and downstream open, with linear extent of hundreds to thousands of meters (Fig. 3). Water depth in the BC varies with the variability of the river stage hydrology; but in average, it reaches $3 \mathrm{~m}$ at the mean

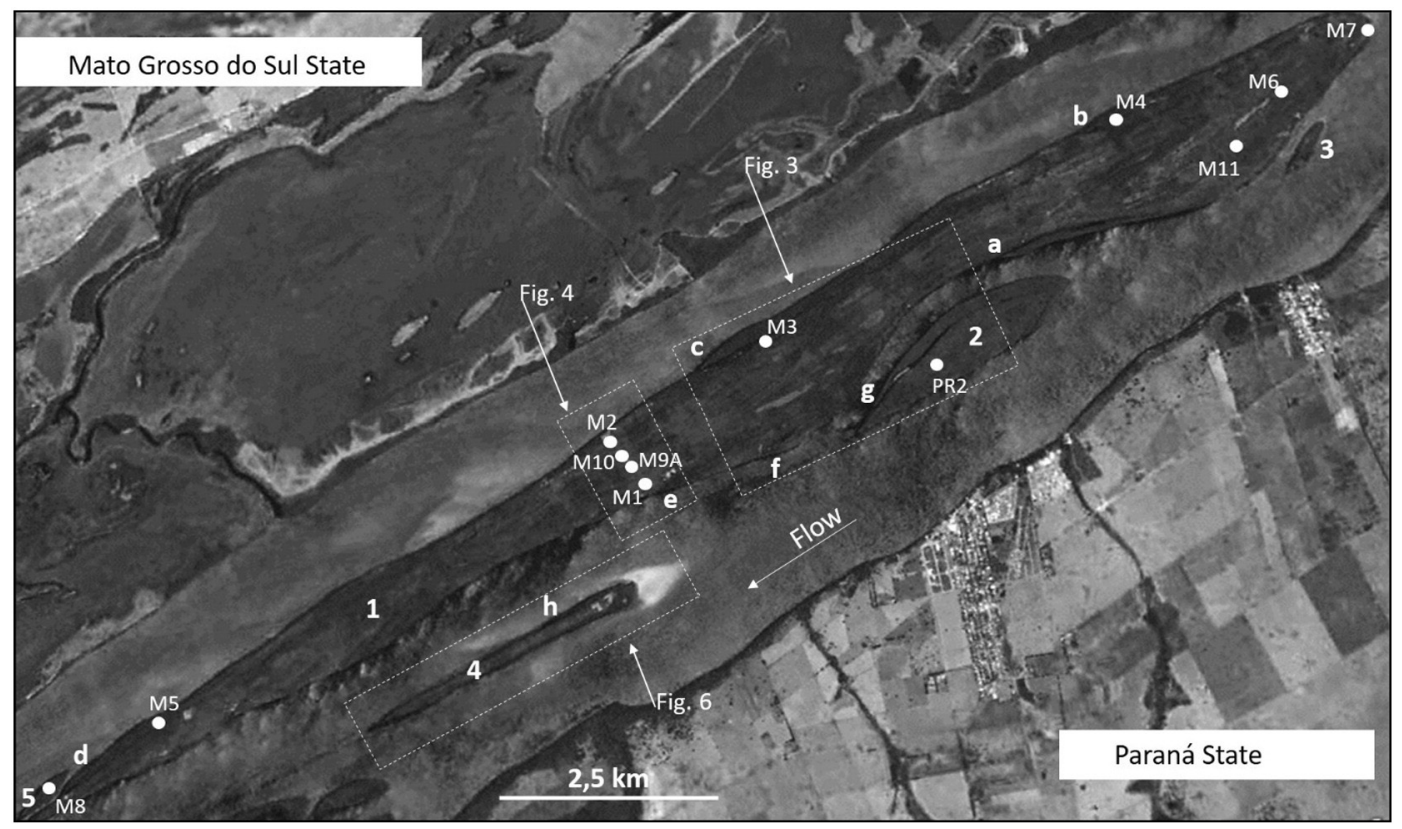

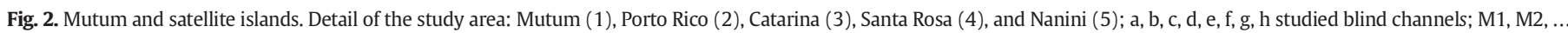
borehole sites. 

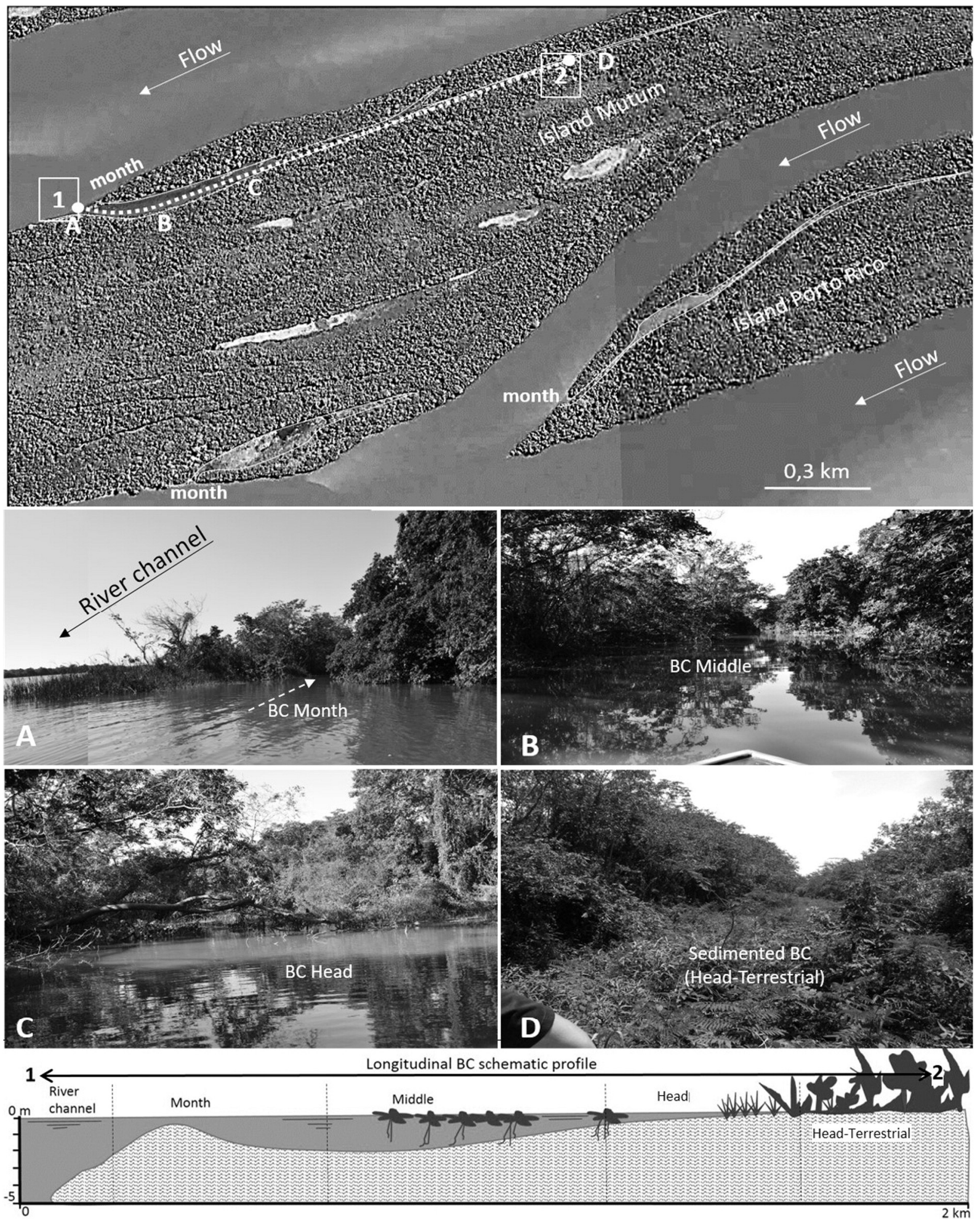

Fig. 3. The $B C$ subenvironments and transversal topographic profile. Top: $B C s$ in the Mutum and Porto Rico Islands (yellow traced lines). See over the island surface the scars of ancient $B C s$ that evolved to elongate lakes or swamps. Middle: The Mutum Island BC subenvironments (see the upper photo for localization). Bottom: Schematic topographic longitudinal profile (with traced line in top photography) (A) mouth reach, note mouth bar with grassy vegetation (eupotamic environment); (B) middle reach, typical channel morphology, but with very low velocity or lentic flow (parapotamic environment); (C) head reach (parapotamic to paleopotamic environment); and (D) head-terrestrial reach (explanation in the text). Topographic data were conducted with transit level and total station. 


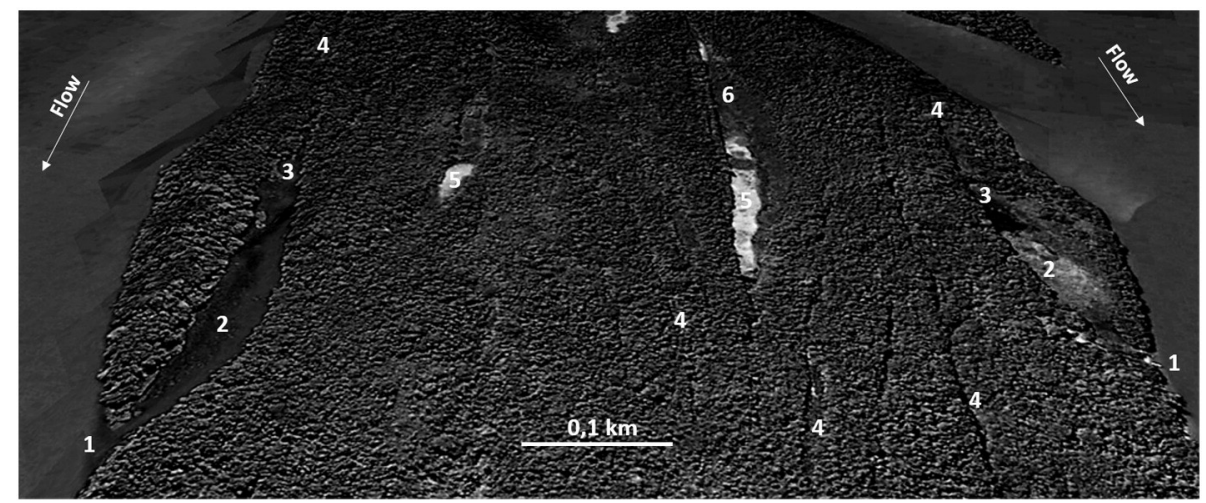

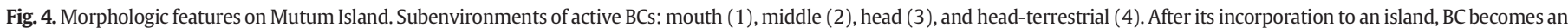
elongated lake (5) and swamp (6).

Table 1

Connectivity degrees and physical characteristics of river channel and $\mathrm{BC}$ reaches.

\begin{tabular}{|c|c|c|c|c|c|}
\hline Reach & River channel & $\begin{array}{l}\text { Mouth } \\
\text { (Fig. 3A) }\end{array}$ & $\begin{array}{l}\text { Middle } \\
\text { (Fig. 3B) }\end{array}$ & $\begin{array}{l}\text { Head } \\
\text { (Fig. 3C) }\end{array}$ & $\begin{array}{l}\text { Terrestrial } \\
\text { (Fig. 3D) }\end{array}$ \\
\hline Flow condition & Lotic & Semilotic & Semilotic- Lentic & Lentic & \\
\hline Connectivity degree $^{a}$ & Eupotamic & Eupotamic-parapotamic & Parapotamic & Paleopotamic & Terrestrial \\
\hline Vegetation & Algae, macrophytes & Macrophytes, algae and grass (in the mouth bar) & Macrophytes, algae and grass & Grass, algae & Shrubs, trees, grass \\
\hline Bottom sediment & Fine-medium sand & Fine-muddy sand & Mud and organic mater & Mud and organic mater & Muddy soil \\
\hline
\end{tabular}

\footnotetext{
a According to Ward and Stanford (1995) classification.
}

water level (Komatsu, 2003; Bubena, 2006). At local scale, depth along the $\mathrm{BC}$ becomes shallow toward the upstream direction (Fig. 2).

The ecological connectivity in the $\mathrm{BC}$ ecosystem also varies with the hydrological river stage and with the position along the channel. Using as a reference the mean annual water stage, characterizing four subenvironments for hydrologic connectivity is possible: mouth, middle, head, and head-terrestrial reaches (Figs. 3, 4; Table 1). The mouth reach is characterized by a eupotamic condition (in the concept of Ward and Stanford, 1995), with an active exchange between the river and $\mathrm{BC}$ water. The sediment transported by the river is deposited in the $\mathrm{BC}$ mouth and forms a blind channel mouth bar that emerges at mean water level (Figs. 3, 4). However, this morphologic feature can be eroded under specific hydrological conditions.
The middle reach undergoes semilotic to lentic flow under parapotamic conditions at the mean river water level. The transference of water from the river channel to the $\mathrm{BC}$ does not occur in the middle reach. It has a predominant influence of terrestrial variables (phreatic water and vegetal remains from trees of the island and soil sediment transported from the island to the $\mathrm{BC}$ by Hortonian flow during the rain). The head reach of the $\mathrm{BC}$ is a paleopotamic swampy environment with root vegetation development. This reach can dry out during low water level stage. The head-terrestrial reach, located in the upstream sector, is very similar to that of the island itself. Shrub and tree vegetation are common, and initial pedogenesis may occur.

The river water level controls the BC hydrology under four conditions (Figs. 2, 3): (i) River phase occurs in high water level with the

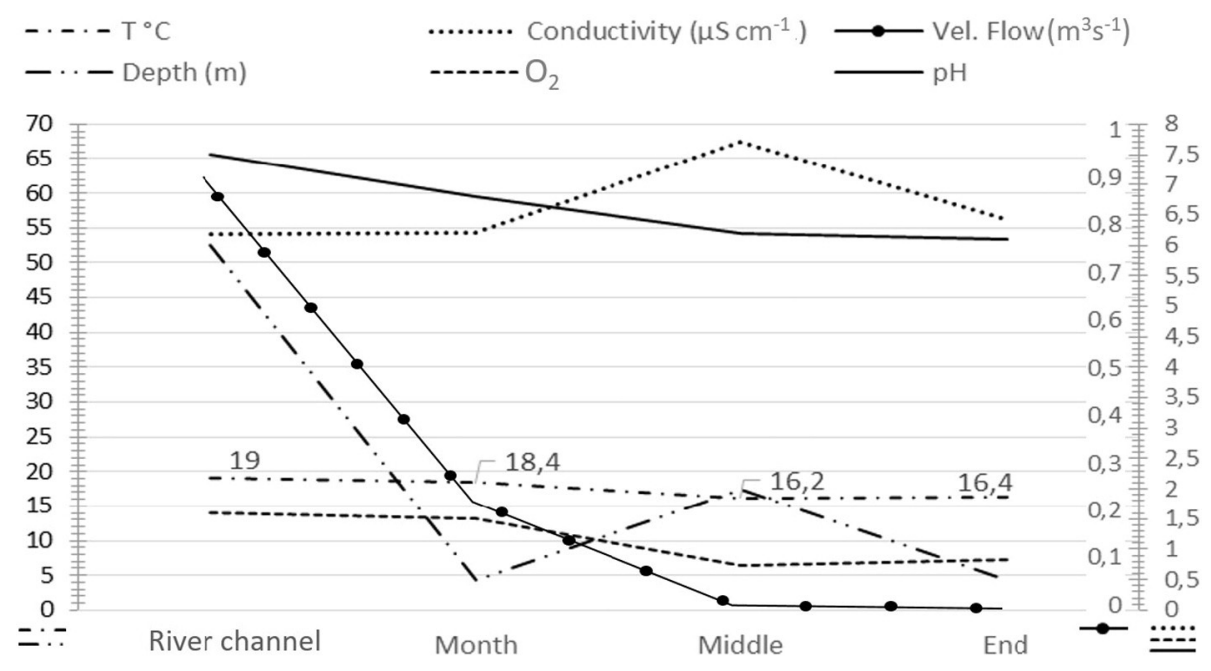

Fig. 5. Abiotic water parameters in river channel and BC reaches in the winter period. 


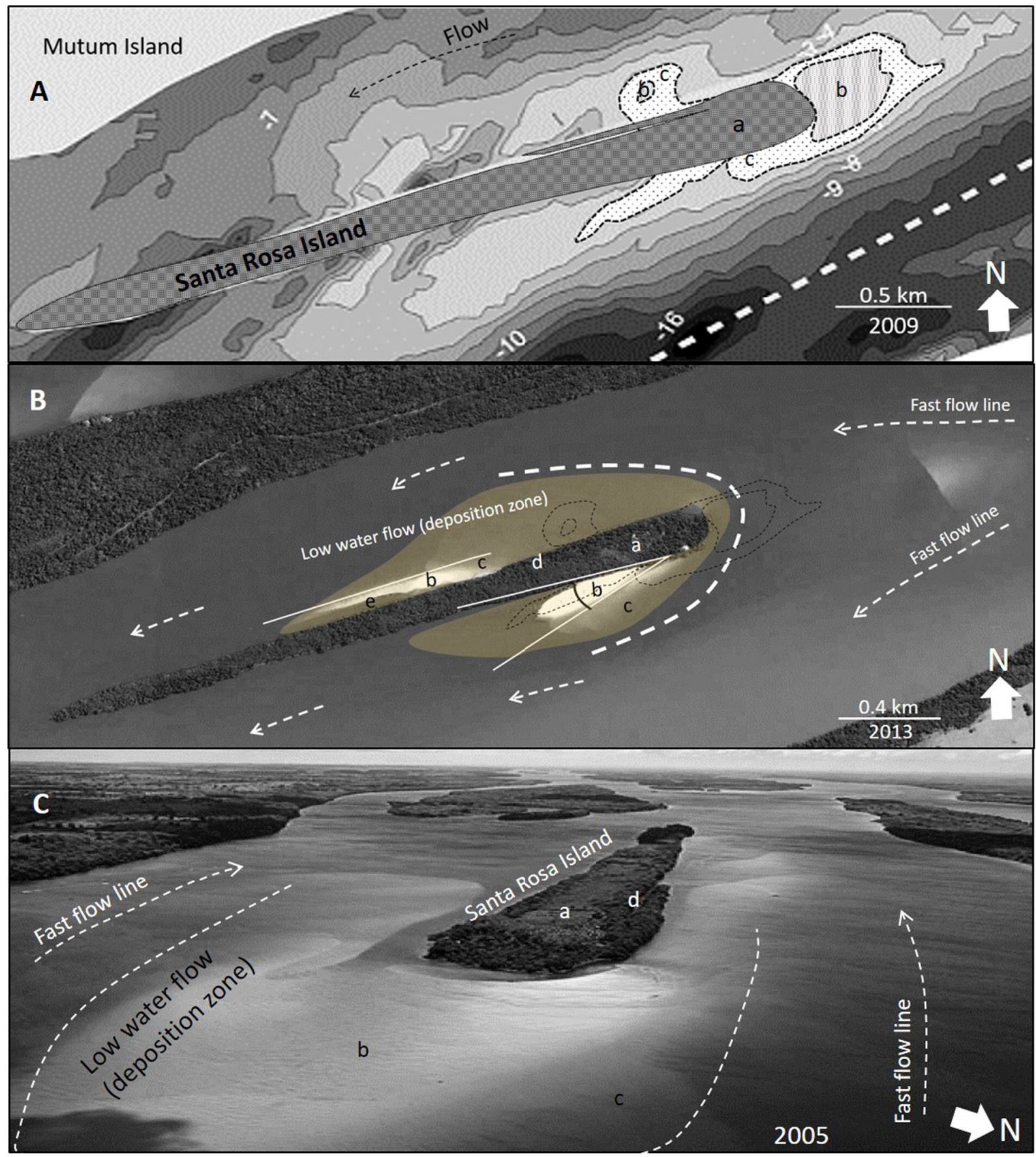

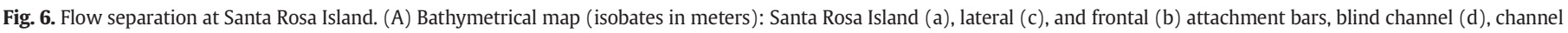

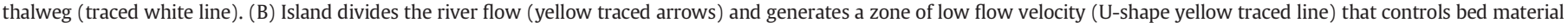

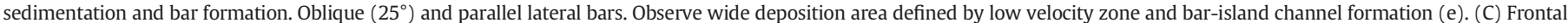

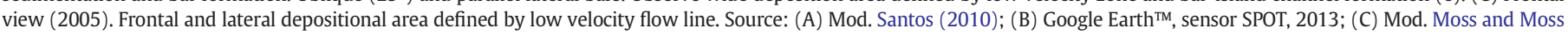
(2005).

water flows into the $\mathrm{BC}$, generating a waning flow into the $\mathrm{BC}$. At this phase, not only water but also sediment, nutrients, and even fish enter into the $\mathrm{BC}$ environment. (ii) BC phase occurs during the water level drop and the water stored in the island runs to the river in an inverse flow through BC. The BC can also trap incoming sediment and organic material (especially vegetal remains) from the island soil erosion; (iii) Lentic phase occurs during major time, in which the water body acts like a pond. This phase is marked by intensive biological activity (Agostinho et al., 2004a, 2004b); (iv) Reactivation phase occurs in extreme floods when the river water overflows the $\mathrm{BC}$, erodes the occluded upstream mouth, and reacts with the ancient bar-island channel (see the definition below of bar-island channel). The reactivation can be temporary or permanent, resulting (sometimes) in a new island.

Physical parameters of a BC's water vary in each subenvironment and for different hydrological phases (Fig. 5; Table 1). Dissolved $\mathrm{O}_{2}$ and $\mathrm{pH}$ decrease from the river channel to the $\mathrm{BC}$. Lentic flow conditions with high biological activity in the $\mathrm{BC}$ consume dissolved $\mathrm{O}_{2}$ and, in extreme cases, tend to eutrophication. High organic content leads to 


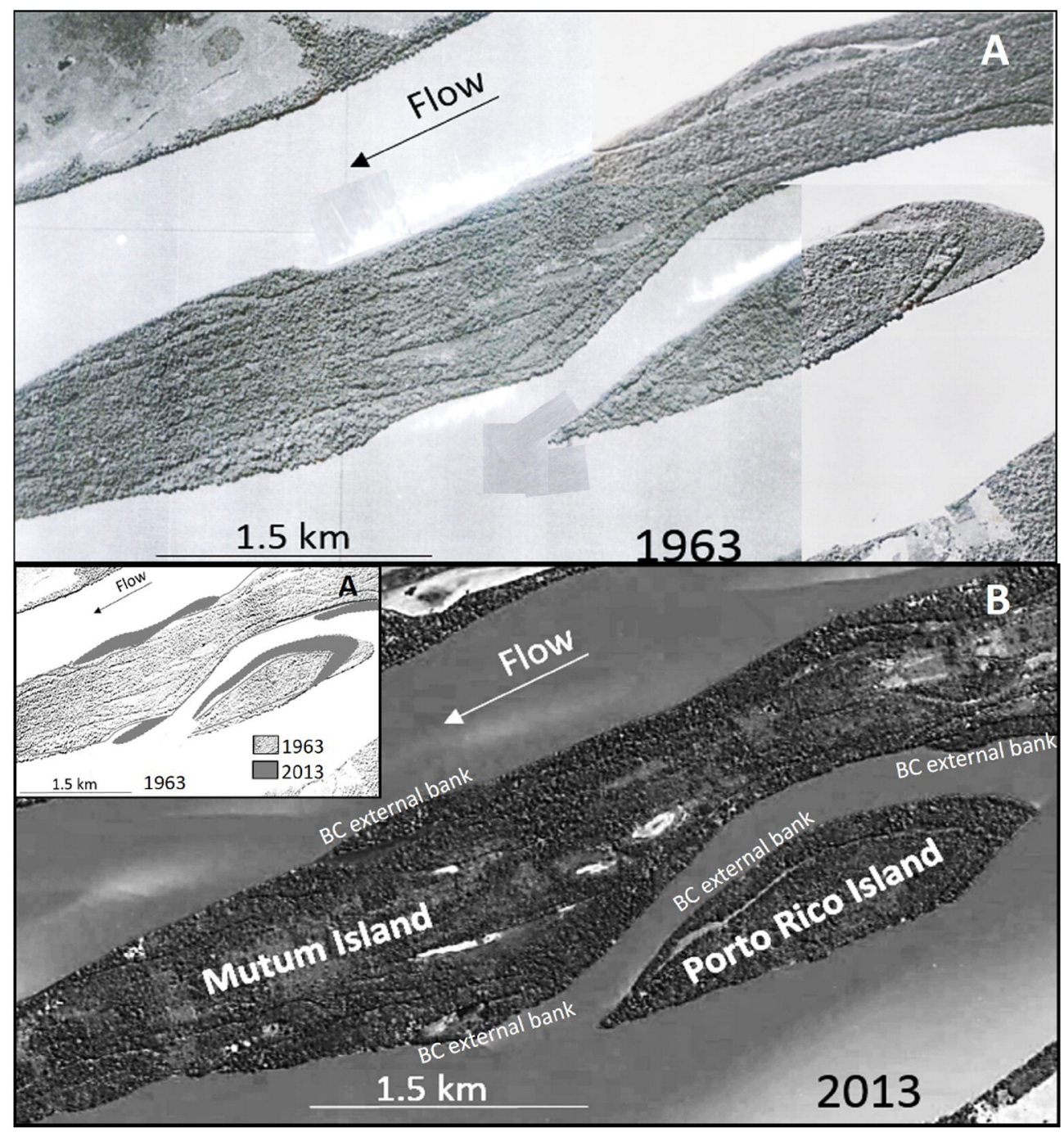

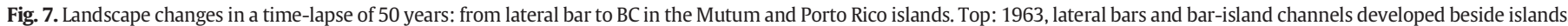
Bottom: situation in 2013. Middle: Yellow areas are island accretion in 50 years. Sources: (A) 1963 aerial photography (ITCF); (B) Google Earth ${ }^{\mathrm{TM}}$, SPOT sensor, 2013.

increasing water acidity ( $\mathrm{pH}$ 6.1), which is lower than the slightly alkaline river water ( $\mathrm{pH} 7.6)$. Once the $\mathrm{BC}$ has shallow depth and slow to lentic flow, high water temperature would be expected; but the opposite happens. Unlikely to expected, the water temperature is $2^{\circ}$ to $3^{\circ} \mathrm{C}$ lower than the river channel water because the $\mathrm{BC}$ is characterized by shady environments, with high trees on the banks, and reduced insolation (Figs. 3, 5).

\section{Genesis and evolution}

The Mutum Island divides the main channel of the Paraná River into two secondary channels: the left one with 1720-m width, Qm $7500 \mathrm{~m}^{3} \cdot \mathrm{s}^{-1}, 5-\mathrm{m}$ average depth, and $10-\mathrm{m}$ thalweg; and the right one with 980-m width, $Q m 2500 \mathrm{~m}^{3} \mathrm{~s}^{-1}$, and 3-m depth average. Flow division generates a U-shape lower velocity zone immediately upstream from the island (Fig. 6).

The low velocity zone prevents bedload transportation, and an elongated bar (lateral and attachment bars) begins to be formed at 10 to $25 \mathrm{~m}$ from the island forming a bar-island channel (Santos, 2010). It marks the beginning of the BC formation (Stevaux, 1994; Santos, 2010). The barchannel width and shape (angle between the bar and island) is controlled by the flow velocity and the island head morphology. Souza Filho (1993), Drago et al. (2013), and Leli (2015) identified similar processes in sand bars formed at the upstream face of islands in the Upper and Lower Paraná River. Between the bar and an island, a bar-island channel is then formed, and the BC originates (Fig. 6). Lateral bar stabilizes by vegetal cover (grass and shrubs), and sand deposition continues to happen in the downstream end by progradation, which leads to an increase in the bar-island channel length. Once stable, the bar evolves by vertical aggradation of fine mud, sandy mud during the floods. The vertical accretion process continues until the bar reaches the island height, which is approximately correlative to bankfull stages. During floods, bed channel sediments, logs, and branches tend to jam the upstream sector of the bar-island that, once attached to the islands or margin banks, create the BC. Island vegetation (trees and shrubs) colonizes the $\mathrm{BC}$ external bank, and the taller species are found in the most emerged areas where vertical aggradation was more active (Zviejkovski, 2013). The evolution of some BCs of the Mutum and Porto Rico islands is compared from 50-year interval images (Fig. 7). In 1963, lateral bars and the corresponding bar-island channels at the right and left margins of the Mutum Island as well as in the right margin of the Porto Rico Island are present. Fifty years after (2013), all the lateral bars are more developed and the presently active BCs were created.

Through time, the downstream mouth of BC can also be closed, forming elongate ponds, which are entirely incorporated to the island (Fig. 3). The continuity of this process gives to the island a peculiar surface morphology with linear parallel scars related to the accretion of ancient BCs (Figs. 3, 4, 7). Overtime, the scars tend to disappear owing to 


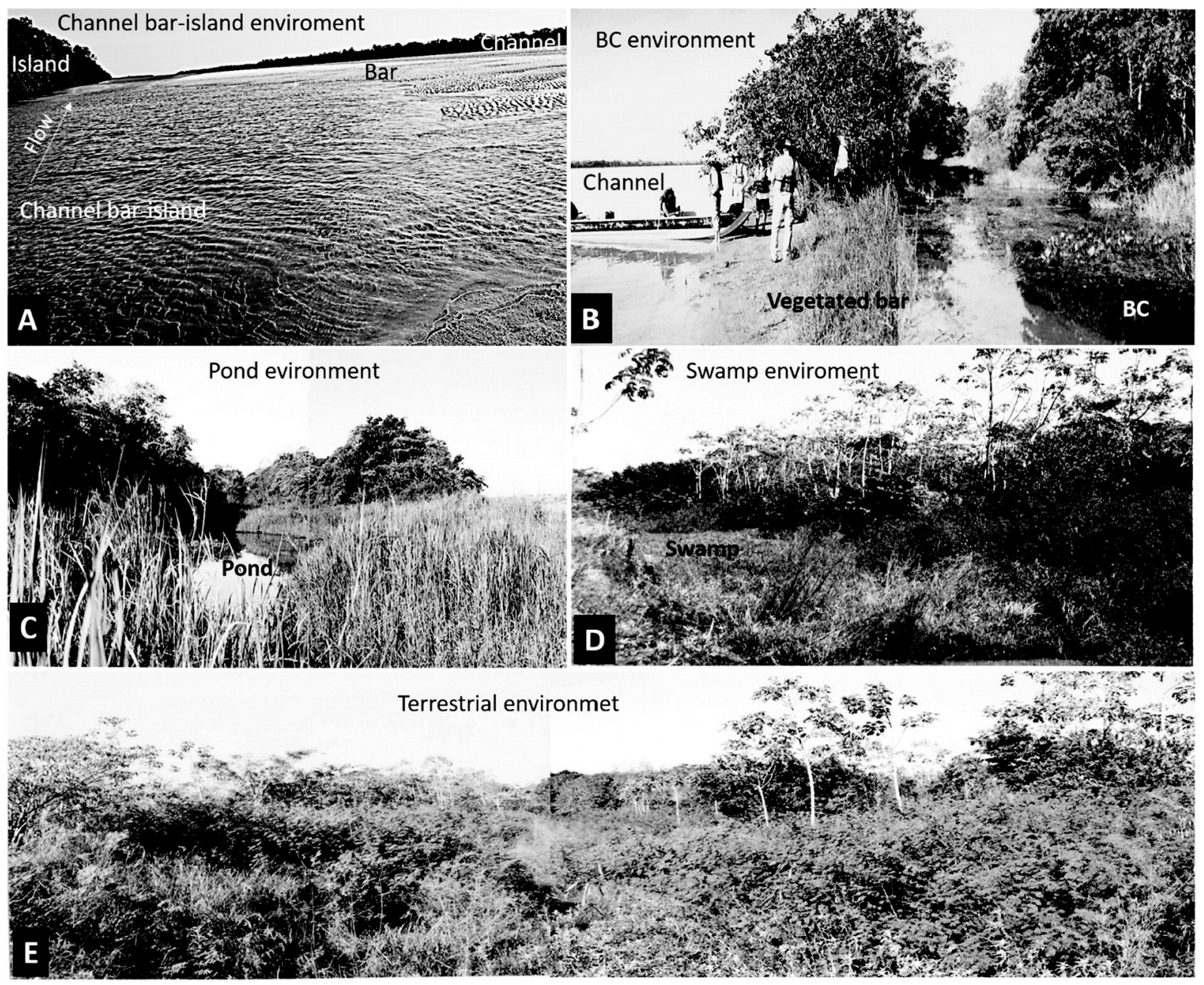

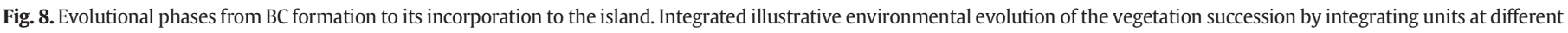

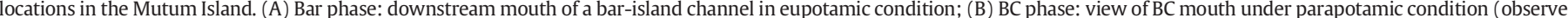

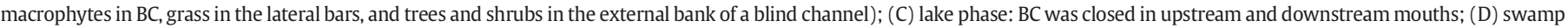
phase: the progressive sedimentation by floods changes lake to swamp; (E) terrestrial phase: island surface is totally covered by tree vegetation typical of island forest.

the continuity of overbank sedimentation, pedogenesis becomes active on the island alluvial deposits, and Eutrophic Neosoil starts to develop (Stevaux et al., 2006). Based on pollen analysis, Zviejkovski (2013) concluded that the complete evolution of the island riparian forest succession over the newly formed surface at the Porto Rico Island took over 150 years (Fig. 8 ).

In summary, formation, evolution, and incorporation of $\mathrm{BC}$ to the island involve five successive phases with the related growing in vertical accretion: 1 - lateral bar deposition and bar-island channel construction (Fig. 8A); 2 - bar-island channel is closed at the upstream end, becoming a BC (Fig. 8B); 3 - BC closes at its downstream end and became transformed in a pond (Fig. 8C); 4 - with the active overbank sedimentation, the pond changes to swamp (Fig. 8D); and 5 - the continuity of overbank sedimentation generates a totally terrestrial condition, and the new surface begins to be colonized by typical riparian forest. Depositional surface can reach the elevation of the major island by vertical accretion (Fig. 8E).

\section{Facies analysis and sedimentation}

As discussed above, once formed, the $\mathrm{BC}$ can be totally incorporated/accreted into the island. The sedimentary record of the $\mathrm{BC}$ evolution and incorporation to island was identified by the analysis of 12 cores drilled in the Mutum and Porto Rico islands (Fig. 2). The complete vertical profile (Fig. 9) for island deposits starts with fine to medium cross-stratified (Facies Sp, St), massive sand (Facies Sm which is related to channel processes and bed sediments), and the generation of lateral bar and the bar-island channel. The channel facies are overlaid by laminated muddy fine sand (Facies Fl) intercalated with massive muds (Facies Fm) and rippled and massive fine sand (Facies $\mathrm{Sr}, \mathrm{Sm}$ ), with vegetal remains (leaves and fragments of branches) deposited in the BC. Organic laminated mud, rich in leaf and branch remains (Facies Fm and Fls), records the pond phase. The preservation of lamination indicates that water depth was sufficiently large to prevent the development of root vegetation and sediment bioturbation. The stage of swamp is identified by mottled mud (Fm facies). Pedogenesis and initial soil formation can be present at the top, evidencing a transitional terrestrial condition.

The $\mathrm{BC}$ vertical accretion rates were estimated by ${ }^{14} \mathrm{C}$ dating of the sediments recovered in Mutum Island (Table 2). In the case observed in the core M1, after bar-island channel, BC acted for 130 years to evolve to pond at a sedimentary rate of $3.8 \mathrm{~mm} \mathrm{y}^{-1}$. The next phase took 400 years (sedimentary rate of $1.5 \mathrm{~mm} \mathrm{y}^{-1}$ ). Terrestrial phase extended for 300 years at a sedimentary rate of $2.6 \mathrm{~mm} \mathrm{y}^{-1}$, with evidence of pedogenesis mainly the last 150 years. It is remarkable that as the age of terrestrial phase formation obtained by facies and chronological analysis is very similar to that obtained for forest formation. Based on botanical criterion 


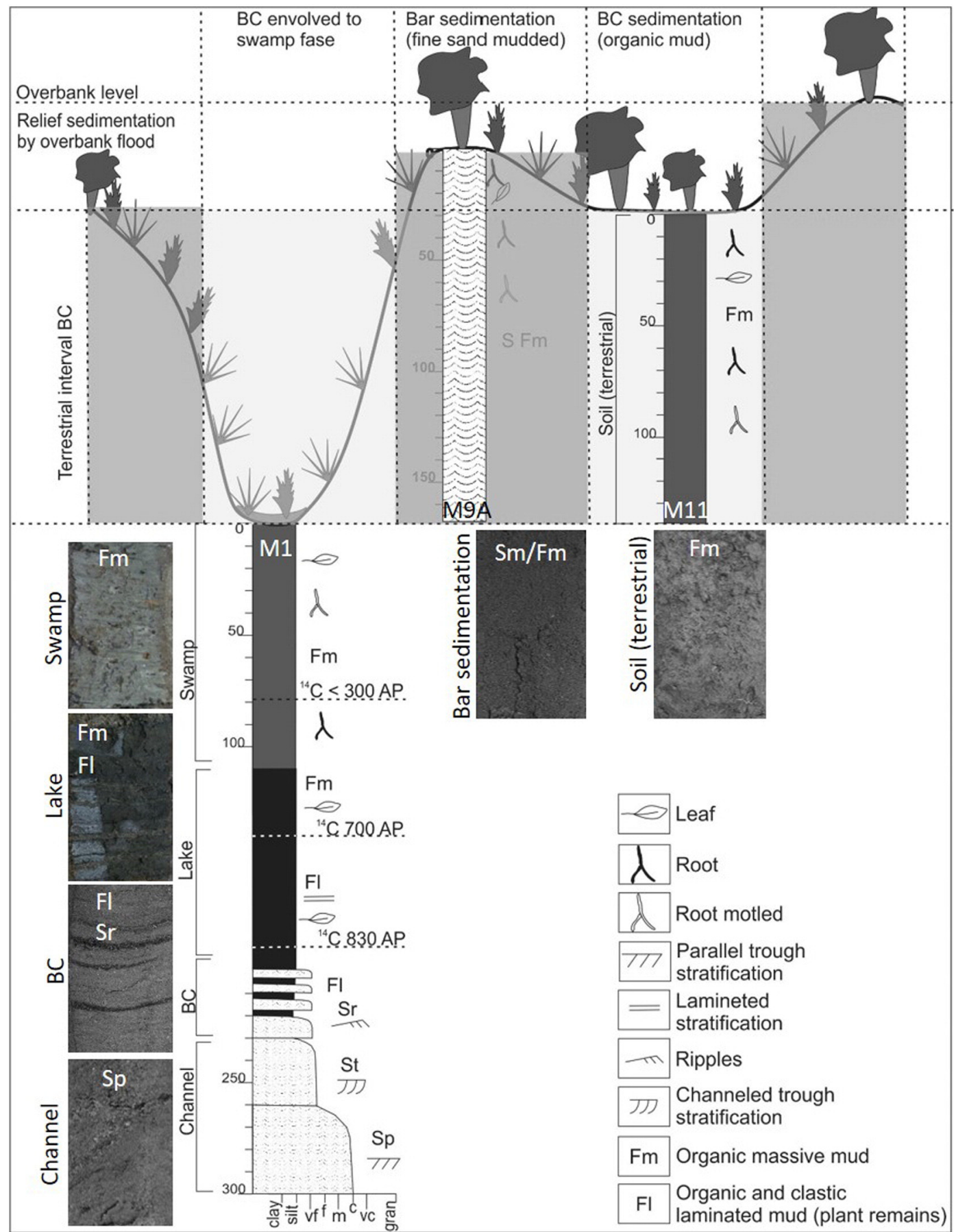

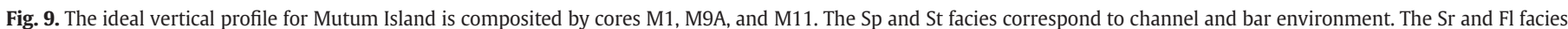
correspond to BC and lake environment; Fm by root bioturbation of the swamp environment and Fm with pedological evidence of island environment. Topography is also schematic.

(trunk diameter), a period of 134 years was estimated for forest installation (Zviejkovski, 2013).

The vertical facies model for the entire sequence of island deposits was constructed by using cores M1, M9A, and M11 (Fig. 9).

\section{Blind channel and island evolution}

The oldest age of sediments observed in the geological cross-section on Mutum Island was ${ }^{14} \mathrm{C} 8200 \mathrm{BP}$ at the center of the island. Younger ages of ${ }^{14} \mathrm{C} 3600 \mathrm{BP},{ }^{14} \mathrm{C} 830 \mathrm{BP}$, and ${ }^{14} \mathrm{C} 700 \mathrm{BP}$ were obtained consecutively from the center to the border (Fig. 10). The nuclear-core island formed around $8.5 \mathrm{ky} \mathrm{BP} \mathrm{(M9A),} \mathrm{when} \mathrm{the} \mathrm{river} \mathrm{bed} \mathrm{was} \mathrm{posi-}$ tioned at a lower level compared to the present. The growing was not gradual, but probably abrupt episodic stages, according to lateral bar and BC formation. Vertical growth developed at a sedimentary rate varying from 0.7 to $3.0 \mathrm{~mm} \cdot \mathrm{y}^{-1}$ (estimated at M1 and PR2). Sedimentary rates are very similar to those found by Stevaux and Souza (2004) for the floodplain in the same area.

A model for island growth by BC accretion in this is postulated in Fig. 11. From a primitive central bar (phase 1), the nuclear island was 
Table 2

Core ages at Mutum and Porto Rico islands, (loc. of cores in Fig. 2).

\begin{tabular}{|c|c|c|c|c|c|}
\hline Core & Depth $(\mathrm{cm})$ & Age (cal. to ${ }^{14} \mathrm{C}$ ) & Dating methods & Location & Laboratory \\
\hline \multirow[t]{3}{*}{ M1 } & 78 & Modern & ${ }^{14} \mathrm{C}$ & $22^{\circ} 45.734^{\prime} \mathrm{S} / 53^{\circ} 17.764^{\prime} \mathrm{O}$ & CAIS \\
\hline & 140 & 700 & ${ }^{14} \mathrm{C}$ & $22^{\circ} 45.734^{\prime} \mathrm{S} / 53^{\circ} 17.764^{\prime} \mathrm{O}$ & CAIS \\
\hline & 190 & 830 & ${ }^{14} \mathrm{C}$ & $22^{\circ} 45.734^{\prime} \mathrm{S} / 53^{\circ} 17.764^{\prime} \mathrm{O}$ & CAIS \\
\hline M2 & 35 & Modern & ${ }^{14} \mathrm{C}$ & $22^{\circ} 45.538^{\prime} \mathrm{S} / 53^{\circ} 17.882^{\prime} \mathrm{O}$ & CAIS \\
\hline M8 & 320 & 585 & ${ }^{14} \mathrm{C}$ & $22^{\circ} 46.724^{\prime} \mathrm{S} / 53^{\circ} 21.088^{\prime} \mathrm{O}$ & CAIS \\
\hline M9A & 515 & 8.200 & ${ }^{14} \mathrm{C}$ & $22^{\circ} 45.700^{\prime} \mathrm{S} / 53^{\circ} 17.778^{\prime} \mathrm{O}$ & CAIS \\
\hline M10 & 450 & 3.600 & ${ }^{14} \mathrm{C}$ & $22^{\circ} 45.593^{\prime} \mathrm{S} / 53^{\circ} 17.854^{\prime} \mathrm{O}$ & CAIS \\
\hline M11 & 200 & 1.700 & ${ }^{14} \mathrm{C}$ & $22^{\circ} 45.170^{\prime} \mathrm{S} / 53^{\circ} 15.621^{\prime} \mathrm{O}$ & BA \\
\hline PR2 & 260 & 920 & ${ }^{14} \mathrm{C}$ & $22^{\circ} 45.448^{\prime} \mathrm{S} / 53^{\circ} 15.946^{\prime} \mathrm{O}$ & CAIS $^{\mathrm{a}}$ \\
\hline
\end{tabular}

CAIS - Center for Applied Isotope Studies, Geórgia, USA; BA - Beta Analytic, Flórida, USA; M = Mutum Island, PR = Porto Rico Island.

a Zviejkovski (2013).

first established. When this island began to divide river flow, the lowvelocity zone was established and the lateral bar began to be formed. Vertical aggradation in this bar permitted BC formation and annexation in phases 2, 3, and 4 . In phase 5, another lateral bar is forming, and the process continued to enlarge the island. The maximum height of the island is reached, controlled by bankfull level. The intensive alteration on sedimentary load introduced by dam regulation prevents the inclusion of hydrosedimentary data in this model.

\section{Conclusion}

Some questions and inferences can be made based on the obtained results concerning $\mathrm{BC}$ processes, morphology, and evolution.

\subsection{Is there a limit for island growth and BC formation?}

In anabranching rivers, where the presence of an island is a necessary fundamental element, BC formation would continuously operate and expand up to reaching a possible equilibrium between valley space availability in straight zones for the available channel width. In the presented study case, the constitution of bank material (hard sandstone in the left margin and cohesive clay deposits in the right one) is a limiting factor for channel width (Stevaux et al., 2013) and consequently for the lateral aggradation of the islands and lateral mobility/migration of the channels.

\subsection{What does history tell facies analysis?}

Although with minor variations, the sedimentary sequence found in island deposits is basically formed by two lithosomes: crossstratified sand covered by organic muddy deposits. This relatively simple lithology, very common in large river architecture (Latrubesse, 2015), is an obstacle for generation of a more realistic facies model. The sandy facies can be interpreted as a lateral bar or other channel bedform. The exact differentiation of both deposits is almost impossible in this case, as their sand grain size and sedimentary structures are practically the same. The muddy sequence can also indicate the different environments with very similar facies. Laminated mud (very fine sandy mud) indicates not continuous sedimentation in a lentic water body deep enough to avoid bottom fixed vegetation and root bioturbation development, suggesting a pond environment. Although there are on studies on this subject, during field work we observed that a $1.0 \mathrm{~m}$ water depth is sufficient to avoid root vegetation but root fixed vegetation increased in shallow water swamps. Thus, mottled mud facies bioturbated by roots are indicators of a swamp environment. Pollen (Gonçaves, 2011) and seed (Ramirez, 2014) analyses in island deposits corroborate the lithofacies interpretation. The occurrence of $\mathrm{BC}$ associated with an island is common in large tropical rivers (Amazon, Negro, Low Paraná), and the accretion of islands to a floodplain is also a characteristic process in these rivers (Stevaux and Souza, 2004; Latrubesse and Franzinelli, 2005; Lewin and Ashworth, 2014; Latrubesse, 2015; Leli, 2015).

\subsection{Can the presented model predict future conditions?}

Although it was not the objective of this paper, some comments can be made about the future changes in the presented model. The construction of the last large dam only $40 \mathrm{~km}$ upstream of the study area (Porto Primavera Dam) introduced several impacts in the river system, especially in the flow regime, suspended sediment concentration (from 30-50 to $0.3 \mathrm{mg} \mathrm{l}^{-1}$ ), and bedload grain size (Stevaux et al., 2009). Under this condition, imagining a reduction or total elimination of the aggradation processes and BC formation is possible. On the other hand, the current clean water increases flow erodibility, and the river tends to recompose its original load by an autophagic process of erosion of the floodplain and the island, as observed and measured by Chien (1984) in a different downstream reach of Chinese dammed rivers. Thus, an imbalance condition imposed by river regulation jeopardizes, the functioning of the river and its dependent ecology. Under these new conditions, the evolution of a BC lateral bar, concerning its vertical

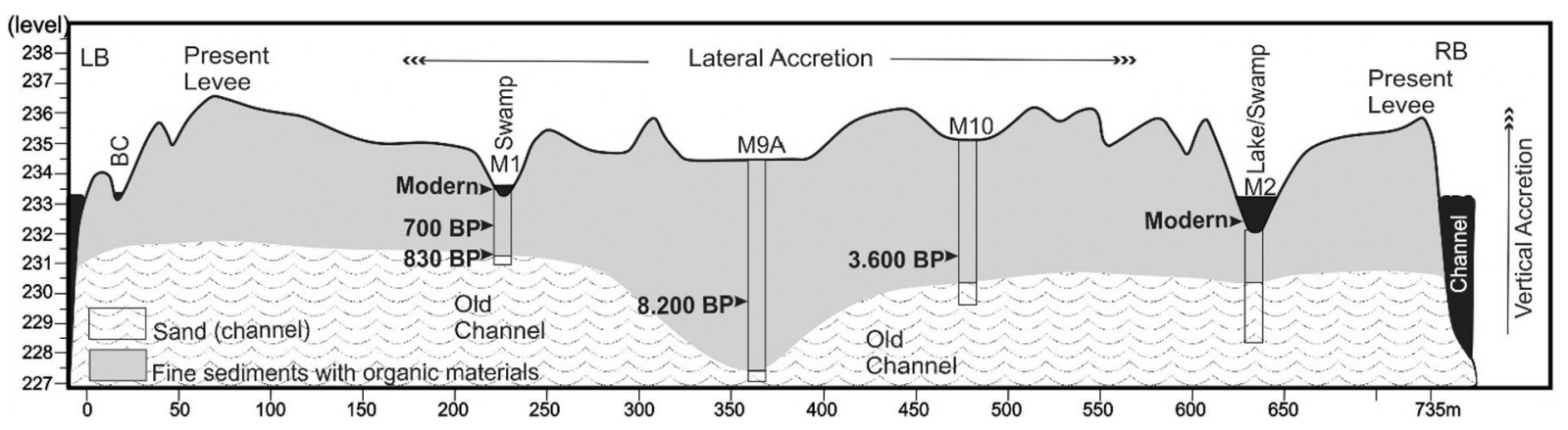

Fig. 10. Topographic and geological cross-section of Mutum Island. Deposits can be divided into sandy (lower) and muddy (upper) lithosomes. 


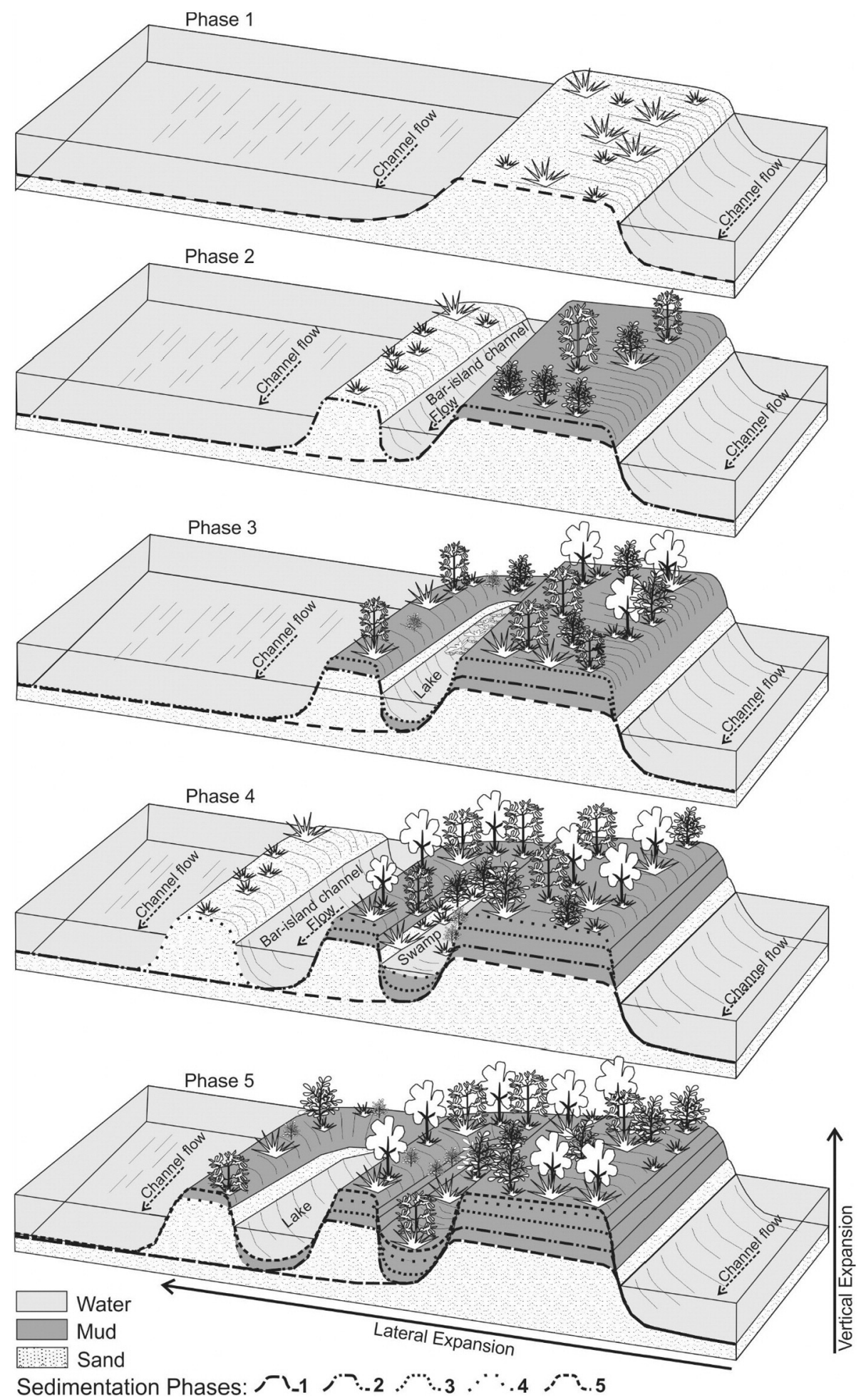

Fig. 11. Model for island growth from $B C$ attachment.

aggradation is strongly disturbed, once large floods and mud supply practically disappeared from the system.

\section{Acknowledgment}

We acknowledge the substantial contribution of the blind referees and in special to Dr. Latrubesse (guest editor) and Dr. Marston by the efforts editing manuscript. We also thank the Brazilian Council of Science and Technology (CNPq) for the grant to J. C. Stevaux (Proc. 474542-2011/ 0) and M. L. Assine (Proc. 308563/2013-1) that supported field and laboratory works and CAPES by Post-doctoral scholarship to the first author. We would like to thank the Group of Environmental Studies (GEMA) and Research Group on Limnology, Ichthyology and Aquiculture (NUPELIA) of the University of Maringá for laboratory and field support. 


\section{References}

Agostinho, A.A., Gomes, L.C., Veríssimo, S.M., Okada, E.K., 2004a. Flood regime, dam regulation and fish in the Upper Paraná River: effects on assemblage attributes, reproduction and recruitment. Rev. Fish Biol. Fish. 14, 11-19.

Agostinho, A.A., Thomaz, S.M., Gomes, L.C., 2004b. Threats for biodiversity in the floodplain of the Upper Paraná River: effects of hydrological regulation by dams Ecohydrol. Hydrobiol. 4 (3), 255-268.

Bubena, M.R., 2006. Lagoas da planície de inundação do alto rio Paraná. (M.Sc. Dissertation). State University of Maringá.

Chien, N., 1984. Changes in river regime after the construction of upstream reservoirs Earth Surf. Process. Landsc. 10, 143-159.

Corradini, F.A., Fachini, M.P., Stevaux, J.C., 2008. Geomorfologia E Distribuição da vegetação ripária na Ilha Mutum, rio Paraná, PR/MS. 27. UNESP, Geociências, São Paulo, pp. 345-354 (3).

Drago, E.C., Amsler, M.L., Paira, A.R. 2013 Recrecimiento aguas arriba de bancos de aren e islas en el río Paraná. Sexto Simpósio Regional sobre Hidráulica de Ríos, Santa Fe, Argentina.

Fachini, M.P., 2001. Fitofisionomia e levantamento florísticos em transectos da planície de inundação do Alto Rio Paraná (PR e MS). (M.Sc. Dissertation). Ecology. State University of Maringá.

Gonçaves, A.C., 2011. Palinologia dos depósitos da ilha Mutum (Alto rio Paraná) como indicadores de processos de conectividade de longa duração. (M.Sc. Dissertation). Ecology. State University of Maringá.

Komatsu, E.H., 2003. Lagoas da Planície Aluvial do Rio Ivinheima - Morfologia e Comunidade Bêntica. (M.Sc. Dissertation). Geography Department. State University of Maringá

Latrubesse, E.M., 2008. Patterns of Anabranching channels: the ultimate end-member adjustments of mega-rivers. Geomorphology 101, 130-145.

Latrubesse, E.M., 2015. Large rivers, megafans and other Quaternary avulsive fluvial systems: a potential "who's who" in the geological record. Earth Sci. Rev. 146, $1-30$.

Latrubesse, E.M., Franzinelli, E., 2005. The late Quaternary evolution of the Negro River Amazon, Brazil: implications for island and floodplain formation in large anabranching tropical systems. Geomorphology 70 (3), 372-397.

Latrubesse, E.M., Stevaux, J.C., 2015. The Anavilhanas and Mariuá Archipelagos: fluvial wonders from the Negro River, Amazon Basin. In: Vieira, B.C., Salgado, A.A.R. Santos, L.J.C. (Eds.), Landscapes and Landforms of Brazil. 267. Springer.
Leli, I.T., 2015. Gênese, evolução e geomorfologia das ilhas e planície de inundação do Alto Rio Paraná, Brasil. (Ph.D. Thesis). Department of Geoscience. State University of São Paulo - UNESP, Rio Claro, São Paulo.

Leli, I.T., Stevaux, J.C., Assine, M.L., 2013. Canal Fechado (Ressaco) em Grandes Sistemas de Rios Anabranching: Exemplo do Alto Curso do Rio Paraná. Sexto Simpósio Regional sobre Hidráulica de Ríos. Santa Fe, Argentina.

Lewin, J., Ashworth, P.J., 2014. The negative relief of large river floodplains. Earth-Sci. Rev. 129, 1-23.

Moss, G., Moss, M., 2005. Brasil das Águas: revelando o azul do verde e amarelo. Ed. Supernova, São Paulo, Brazil.

Ramirez, A.I., 2014. Uso de sementes semi-fósseis como "proxy" em sedimento de rio anabranching: o caso do alto rio Paraná. (Ph.D. Thesis). Ecology. State University of Maringá, Maringá, PR, Brasil.

Santos, V.C., 2010. Processos fluviais em barras de soldamento: Rio Paraná, PR. (M.Sc. Dissertation). Department of Geoscience. State University of São Paulo - UNESP, Rio Claro, São Paulo.

Souza Filho, E.E., 1993. Aspectos da geologia e estratigrafia dos depósitos sedimentares do rio Paraná em Porto Primavera (MS) e Guaíra (PR). (Ph.D. Thesis). Geosciences. University of São Paulo.

Stevaux, J.C., 1994. The Upper Paraná River (Brazil): geomorphology, sedimentology and paleoclimatology. Quat. Int. 21, 143-161.

Stevaux, J.C., Souza, I.A., 2004. Floodplain construction in an anastomosed river. Quat. Int. $14,55-65$.

Stevaux, J.C., Barczyskyn, O., Medianick, S., Nóbrega, M.T., 2006. Characterization and environmental interpretation of a floodplain Holocene paleosoil: Implicationsfor paleoydrological reconstructions in the Upper Paraná River, Brazil. Z. Geomorphol. Suppl. 145, 191-206.

Stevaux, J.C., Martins, P.D., Meurer, M., 2009. Changes in large tropical river: the Paraná River downstream from the Porto Primavera Dam, Brazil. Geomorphology 113, 230-238.

Stevaux, J.C., Corradini, F.A., Aquino, S., 2013. Connectivity processes and riparian vegetation of the upper Paraná River, Brazil. J. S. Am. Earth Sci. 46, 113-121.

Ward, J.V., Stanford, J.A., 1995. Ecological connectivity in alluvial river ecosystem and its disruption by flow regulation. Regul. Rivers Res. Manag. 11, 105-119.

Zviejkovski, I.P., 2013. Ecologia de florestas tropicais. Sucessão ecológica. Deposição serapilheira. Insetos edáficos. Insetos de solo. Grupos tróficos. Florestas secundárias. Ciclagem de nutrientes. Planície de inundação. Alto rio Paraná. Brasil. (Ph.D. Thesis). Ecology. State University of Maringá, Maringá, PR, Brazil. 